\title{
Tradição, identidade nacional e modernidade em Joaquim nabuco
}

Ricardo Luiz de Souza*

Resumo. A obra de Joaquim Nabuco articula análise política e social, tomando, em uma primeira etapa, o abolicionismo como eixo. Em uma segunda etapa, que toma como divisor de águas a Abolição e a República, ganha vulto o historiador e memorialista, preocupado com o resgate e preservação de tradições ligadas ao período monárquico. O objetivo do texto é analisar a evolução do pensamento do autor, tomando ambas as fases como parâmetro, bem como sua discussão sobre identidade nacional, tradição e modernidade.

Palavras-chave: Monarquia. Tradição. Modernidade. Política.

\section{Cultura e identidade nacional}

Parto de um episódio específico que ajuda a entender o pensamento de Joaquim Nabuco: ele saúda o povo por dar vivas à Abolição, em 1886, mas define-o como "camadas espontâneas e quase infantis" nas quais bate o "coração brasileiro", em contraste

*Ricardo Luiz de Souza é Doutorando em História pela UFMG.

Anos 90, Porto Alegre, v. 11, n. 19/20, p.319-346, jan./dez. 2004 
Tradição, identidade nacional e modernidade em Joaquim Nabuco

com as correntes plutocráticas que, segundo ele, dominam o Rio de Janeiro (Nabuco, 1949a, p.236). Afloram, nesse trecho, as contradições do autor: a identidade nacional encarna-se no povo, mas este é definido como quase infantil e, portanto, incapaz de agir autonomamente. A perspectiva de uma sociedade débil e amorfa perante as imposições das elites fundamenta as análises de Nabuco.

A estrutura partidária brasileira comprometia-se irremediavelmente devido à virtual inexistência de uma população formada por cidadãos ativos politicamente que serviriam de fundamento indispensável à representação partidária: pela ausência de povo. Com isso, o abolicionismo deveria ser um movimento apartidário por uma questão de necessidade. Comprometidos com o status quo, os partidos seriam para a causa de pouca ou nenhuma valia. Daí a necessidade de passar ao largo das instâncias partidárias.

Tal necessidade deriva do fato de o artificialismo do sistema partidário decorrer da inexistência de uma opinião pública que o sustente; daí a necessidade que os partidos sentem de apoiarem-se no Imperador, para ele fazendo política e dele servindo de instrumentos (Nabuco, 1949a, p.215). A conclusão decorrente de tal constatação é a de que qualquer tentativa de criação de um sistema partidário autenticamente representativo estará fadada ao fracasso enquanto não existir uma opinião pública por trás desse sistema. Tal conclusão leva a própria ação política do autor, contudo, a um impasse, uma vez que suas próprias tentativas de reforma carecem de fundamento. Dada a inexistência dessa opinião pública, finda a monarquia, o Exército surge, para Nabuco, como a única instituição genuinamente nacional, neutra e desinteressada politicamente, ou seja, a única instituição capaz de exercer o poder no lugar da monarquia (Nabuco, 1949a, p.70).

Nabuco foi abolicionista, mas foi monarquista também: monarquista e federalista. Em suas palavras: "Acredito ser de vantagem para o país que o ensaio da federação, julgo uma fortuna para o país, seja feito sob a forma monárquica" (Nabuco, 1983, p.366), e seu federalismo deve ser pensado no contexto de seu 
abolicionismo, assim como seu monarquismo deve ser pensado no contexto de seu arraigado tradicionalismo.

Referindo-se à luta norte-americana pela emancipação dos escravos, Rosa Luxemburgo associa o regionalismo à defesa da escravidão, enquanto atribui ao centralismo capitalista a luta pela abolição (Luxemburgo, 1988, p.90). No Brasil, o processo deu-se de forma invertida e foi, certamente, um dos fatores que condicionaram a defesa do federalismo feita por Nabuco. Mas esse não foi o único determinante: a distância entre as províncias, sua diversidade de interesses e necessidades e a impossibilidade de impedir sua absorção pelo Estado, a não ser que fosse dada a elas autonomia absoluta, foram fatores que justificariam, igualmente, a implementação do sistema no Brasil (Nabuco, 1949a, p.170).

O projeto político de Nabuco previa a compatibilização entre monarquia e federalismo. Definia-a, mesmo, como indispensável à vida política brasileira. Seu projeto, segundo Oliveira Vianna, previa não apenas a descentralização, mas a federação ampla, e tinha como ponto essencial a eletividade dos presidentes provinciais. Mas era intransigentemente monarquista, diferindo, nesse aspecto, do federalismo de um Rui Barbosa: "Rui queria a federação, mas era indiferente à monarquia; Nabuco, ao contrário, idealizava a federação com a monarquia e temia aquela sem esta" (Vianna, 1990, p.45).

Com a abolição, o abolicionista e monarquista torna-se, nas palavras de Nogueira (1984, p.130), apenas monarquista. A percepção crítica do papel da monarquia transforma-se em apologia desta. Nabuco sente-se à vontade, por exemplo, para retratar-se, em Minha Formação, como o aristocrata europeizado que nunca deixou, efetivamente, de ser. A análise da identidade nacional serve de base, também, para seu monarquismo. O problema brasileiro não é institucional, e sim de identidade: "não são as instituições que não tem raízes; é o solo que não têm consistência e cujas areias o menor vento revolve... Nenhum terreno pode ser mais próprio do que esse para a cultura da anarquia" (Nabuco, 1990, p.43.5).

A queda da monarquia não se deveu, portanto, a eventuais falhas do regime monárquico, mas à inconsistência do Brasil

Anos 90, Porto Alegre, v. 11, n. 19/20, p.319-346, jan./dez. 2004 
Tradição, identidade nacional e modernidade em Joaquim Nabuco

enquanto nação, inconsistência essa, contudo, que reclamava a existência de um regime monárquico. Para Nabuco, "o Brasil quanto mais civilizado mais tenderá para a monarquia; quanto mais bárbaro, mais se desinteressará dela" (Nabuco, 1990, p.48).

O monarquismo de Nabuco deriva, assim, de uma questão identitária. Referindo-se às suas convicções políticas à época da abolição, ele afirma: "Neste último período a noção de monarquia para mim era esta: a tradição nacional posta ao serviço da criação do povo, o vasto inorganismo que só em futuras gerações tomará forma e desenvolverá vida" (Nabuco, 1949b, p.54). O povo brasileiro ainda não existia, nem existiria tão cedo. Não tínhamos, ainda, uma identidade nacional, e a função da monarquia seria a de operar como uma tradição brasileira capaz de servir como base para a gestação dessa identidade.

Cultura e identidade nacional são, igualmente, questões indissociáveis na obra de Nabuco, e, nela, a cultura é uma questão sempre contraditória. O autor define-a como expressão da nacionalidade: "a alma do escritor é feita em grande parte de sua língua” (Nabuco, 1949c, p.135), e Nabuco foi, como intuiu Tristão de Athayde, uma expressão literária dedicada à política: "Ele veio como uma expressão literária palpável e viva, dessa longa inspiração desperdiçada para as letras entre as paredes das duas Câmaras" (Athayde, 1990, p.241). Ao mesmo tempo, Nabuco reconhece sua europeização: "não revelo nenhum segredo, dizendo que insensivelmente a minha frase é uma tradução livre, e que nada seria mais fácil do que vertê-la outra vez para o francês do qual ela procede" (Nabuco, s.d., p.77). Nesse sentido, na obra de um viajante francês contemporâneo de Nabuco, encontramos uma descrição que parece referir-se a ele: "Há nesse país homens de cultura requintada, donos de uma ciência sadia e profunda; seu espírito é filho do espírito francês; seus mestres são nossos mestres, nossos sábios, e eles reivindicam com orgulho tal parentesco intelectual" (Leclerc, 1942, p.161).

Nabuco não demonstra ainda, na construção do mosaico de idéias algumas vezes pouco compatíveis que forma a sua obra, a

Anos 90, Porto Alegre, v. 11, n. 19/20, p.319-346, jan./dez. 2004 
preocupação tão comum a seus contemporâneos de manter-se a par da última moda européia, mesmo que tal moda tivesse pouco ou nada a ver com a realidade brasileira e nem fosse tão última assim. Apesar disso, seu pensamento é assumidamente europeizado. Nesse sentido, Nabuco é antiquado porque sua sensibilidade é antiquada, e não se tornou mais de bom tom a partir dos padrões nacionalistas afinal imperantes na cultura brasileira. Como acentua Mello,

Boa parte do interesse de Minha Formação consiste precisamente em exprimir a antiga sensibilidade brasileira da Monarquia e da República Velha, repudiada pela sua sucessora, a cultura que se tornou hegemônica a partir dos anos vinte e trinta do século XX e que atualmente ainda é a nossa, embora caiba indagar por quanto tempo ainda (Mello, 2002, p.234).

André Rebouças (1938, p.185) define a França como "minha pátria científica", assim como Nabuco menciona "a construção francesa do meu espírito" (Nabuco, s/d, p.56): a formação de ambos foi essencialmente européia e, neste ponto, o autor define-se como representativo da elite brasileira ou, pelo menos, de seu imaginário:

Nós, brasileiros, o mesmo pode-se dizer dos outros povos americanos, pertencemos à América pelo sedimento novo, flutuante, do nosso espírito, e à Europa, por suas camadas estratificadas. Desde que temos a menor cultura, começa o predomínio destas sobre aquele. A nossa imaginação não pode deixar de ser européia (Nabuco, s/d, p.47).

Quando faz tal afirmação, entretanto, Nabuco está descrevendo o imaginário da elite a qual pertenceu, imaginário que não era, por exemplo, o de Sílvio Romero e Euclides da Cunha, autores profundamente nacionalistas. Para ele, o brasileiro não tem uma mentalidade nacional, sua mentalidade é parisiense (Nabuco, 1949b, p.44), mas a atração exercida pela Europa sobre nossos homens de

Anos 90, Porto Alegre, v. 11, n. 19/20, p.319-346, jan./dez. 2004 
Tradição, identidade nacional e modernidade em Joaquim Nabuco

letras é definida como uma atração perigosa (Nabuco, 1949a, p.177). Não é à-toa, assim, que a habilidade com a qual ele se expressa em francês é reconhecida por Émile Faguet, um escritor francês contemporâneo de Nabuco, citado por Fréches:

Na verdade, teremos a agradável surpresa de descobrir um estrangeiro que maneja nossa língua com facilidade, habilidade, vigor e elegância. Quase seria preciso remontar ao século XVIII para encontrar um escritor não francês capaz de se exprimir com esse virtuosismo (Fréches, 1969, p.117).

Mencionando tal episódio, Freyre define o livro de Nabuco como um "livro do mil e novecentos brasileiro que marcou uma como oposição, involuntária mas significativa, a Os Sertões" (Freyre, 1959 , v. II, p.640.1).

O Euclides nacionalista e o Nabuco europeizado: essa dualidade tornar-se-ia um lugar comum na cultura brasileira, e Nabuco seria, a partir dela, transformado em representante de uma característica cultural que Belo definiria, nos anos, 30, referindo-se ao autor: "Vivemos com os olhos eternamente alongados sobre o Atlântico, numa nostalgia incurável e cujas raízes parecem mergulhadas no passado milenário de alguns países da Europa ocidental, principalmente a França" (Belo, 1935, p.78).

É a partir dessa encruzilhada entre nacionalismo e europeísmo que Nabuco busca definir a identidade nacional. Segundo ele, "no futuro, só uma operação nos poderá salvar - à custa de nossa identidade nacional - isto é, a transfusão do sangue puro e oxigenado de uma raça livre" (Nabuco, 1977, p.60). Para redimir-se das conseqüências da escravidão, o Brasil deveria abandonar sua própria identidade nacional, contaminada por aquela. A salvação nacional estaria, portanto, na imigração. Nabuco postula "um país onde todos sejam livres; onde, atraída pela franqueza das nossas instituições e pela liberdade do nosso regímen, a imigração européia traga sem

Anos 90, Porto Alegre, v. 11, n. 19/20, p.319-346, jan./dez. 2004 
cessar, para os trópicos uma corrente de sangue caucásico, vivaz, enérgico e sadio" (Nabuco, 1977, p.202).

Segundo Tocqueville (1977, p.153), "é um fato constante que, hoje em dia, nos Estados Unidos, os homens mais notáveis raramente são chamados às funções públicas, e fica-se obrigado a reconhecer que isso tem sido assim na medida em que a democracia ultrapassou todos os seus antigos limites". A análise de Nabuco repete a conclusão de Tocqueville, quando ele afirma: "A consciência pública americana é muito inferior à privada, a moral do Estado à moral da família" (Nabuco, s/d, p.173). Nabuco, de fato, mantém-se infenso à influência norte-americana e ele confessa que, mesmo em Nova Iorque, se mantinha sob a influência européia, conservando-se alheio à influência americana (Nabuco, s/d, p.167). A cultura superior não necessita, segundo ele, de nenhum contingente americano, e a política, ali, é vista por ele com desprezo.

Já em relação à Europa, ocorre uma inversão completa. Nabuco dedica uma boa parte de Minha formação a descrever suas relações com o pensamento europeu e, basicamente, com os pensamentos francês e inglês, o que o leva a divagar: "Às vezes me distraio a pensar que povo eu salvaria, podendo, se a humanidade se devesse reduzir a um só... Entre a França e a Inglaterra, fico sempre incerto" (Nabuco, s/d, p.106).

\section{Elite e tradição}

Em que pese o grau de autonomia inerente à ação humana, toda ação é, em maior ou menor intensidade, condicionada pelo sistema social. Popper busca explicar tal processo: "não podemos impor nossos interesses ao sistema social; em vez disso, o sistema nos impõe o que somos levados a acreditar como sendo os nossos interesses. Faz isso forçando-nos a agir de acordo com o nosso interesse de classe" (Popper, 1974, v. 2, p.121). Partir desse axioma de Popper ajuda-nos a compreender como Nabuco descreve a elite pernambucana, da qual é descendente e com a qual se relaciona, e a entender como ele se posiciona perante o que considera serem suas tradições.

Anos 90, Porto Alegre, v. 11, n. 19/20, p.319-346, jan./dez. 2004 
Tradição, identidade nacional e modernidade em Joaquim Nabuco

Nabuco esmera-se na descrição de uma elite cujos valores, para ele, referem-se a uma época na qual os padrões dominantes são incompatíveis com os padrões capitalistas, tendo o autor idealizadoos a partir dessa incompatibilidade. Defendendo a existência histórica de tais valores, Nabuco estabelece uma dualidade que será retomada, entre outros autores, por Florestan Fernandes, ao estabelecer uma dicotomia entre o fazendeiro interessado primordialmente na manutenção do status senhorial e o fazendeiro cujo comportamento pauta-se pelo interesse na obtenção de lucros (Fernandes, 1975, p.111).

Tais valores tendem, ainda, ao desaparecimento; são antiquados, inviáveis, e essa constatação, em Nabuco, é tingida de uma nostalgia melancólica. Realçando o acento evidentemente nostálgico do autor, Scwharz afirma que "Nabuco buscava decantar a parte boa da experiência brasileira, que em seu argumento prosperava quando a economia brasileira se apartava do espírito comercial" (Schwarz, 1997, p.137).

Nabuco é representante de uma elite, e ele a defende e proclama suas virtudes, virtudes que são as da fidalguia pernambucana, a qual, como ele escreve, "tinha um pejo invencível em matérias de dinheiro: como que pegava nas cédulas nas pontas dos dedos" (Nabuco, 1936, v. I, p.319). Essas palavras seriam repetidas por Oliveira Vianna em sua descrição da mentalidade aristocrática:

O nobre o considerava sujo; as suas mãos não estariam limpas se tocassem no dinheiro, se se maculassem com o seu azinhavre; não fazer passar por elas nada que representasse dinheiro ou proveito expresso ou concretizado nele - eis o timbre da verdadeira nobreza (Vianna, 1958, p.135).

Ao elogio da fidalguia pernambucana, pode ser contraposta a crítica à corrupção republicana, expressa na correspondência de Nabuco a partir da Proclamação. Em 1891, ele já afirma: "O Brasil, ou melhor, o Rio de Janeiro, está como a Califórnia, quando se

Anos 90, Porto Alegre, v. 11, n. 19/20, p.319-346, jan./dez. 2004 
descobriu o ouro, ou a África Austral com a descoberta dos diamantes. É uma grande feira a que afluem os aventureiros do mundo inteiro para enriquecerem de repente" (Nabuco, 1949d, v. I, p.198).

No ano seguinte, ao retornar ao Brasil, ele retoma o tema da decadência: "Vou assim assistir da própria cena ao descalabro progressivo do nosso país... No Brasil conservar-me-ei afastado de tudo como no estrangeiro" (Nabuco, 1949d, v. I, p.214). A decadência, por sua vez, gera a inércia forçada: "Não vejo em que empregar atividade e esforço, estando tudo tão moralmente apodrecido" (Nabuco, 1949d, v. I, p.223). A imagem recorrente quando Nabuco refere-se à República é a de apodrecimento. Em 1895, ele retorna a ela: "A situação aqui é apática, triste, desanimada, expressiva da ansiedade, ou antes da incerteza, da indiferença, do vazio, que há em todos os espíritos, em todos os corações. Em uma palavra apodrecemos" (Nabuco, 1949d, v. I, p.255). Finalmente, em 1897, novamente aparece a imagem do declínio: "Eis ao que reduziram o nosso país. De um povo honesto e sério que éramos tiraram essa escória sanguinária e epiléptica que hoje nos governa, dominando as ruas e impondo ao governo" (Nabuco, 1949d, v. I, p.274). No Brasil republicano, os valores da fidalguia pernambucana perderam-se definitivamente; tornaram-se anacrônicos.

Tal perda, contudo, tem origem em um tempo bem mais remoto. Dessa forma, narrando a chegada de seu pai à Câmara, em 1843, Nabuco descreve um processo de transição no qual valores morais e sociais vigentes no Primeiro Reinado desapareciam ou tornavam-se obsoletos em contato com uma sociedade cada vez mais mercantilizada, sendo tal desaparecimento por ele narrado em tom de evidente desgosto. Segundo Nabuco,

Uma nova camada social alastrava tudo, o próprio Paço; as antigas famílias, o resto da sociedade que se reunia em torno de Pedro I, agora tratavam de ocultar do melhor modo que podiam sua irremediável decadência. Aquela sociedade, em uma palavra, 
Tradição, identidade nacional e modernidade em Joaquim Nabuco

desaparecera, com seus hábitos, sua etiqueta, sua educação, seus princípios e os que figuravam agora no fastígio eram os novos políticos saídos da revolução ou os comerciantes enriquecidos. Tudo o mais recuava para o segundo plano: a política e o dinheiro eram as duas nobrezas reconhecidas, as duas rodas do carro social (Nabuco, 1936, v. I, p.38).

Nabuco de Araújo era de outro tempo e de outra estirpe. Era um aristocrata pernambucano e, nesse contexto, seu grande mérito foi exatamente o de pertencer a um outro tempo: seus valores eram outros, alheios ao mercantilismo de sua época:

O velho Nabuco possuía com efeito os dois grandes temores, o de Deus e o da opinião, que são a única salvaguarda da vida. A hierarquia consolidara-se nele como um sentimento do qual todos os outros recebiam o calor e por isto a vida para ele era o respeito; as satisfações que a prática desse sentimento pode dar foram o seu maior gozo (Nabuco, 1936, v. I, p.91).

Aqueles eram, portanto, valores de outros tempos e, com o desaparecimento dos valores próprios à monarquia, desapareceram também, para Nabuco, o que Resende de Carvalho chama de condições de formação de uma personalidade exemplar (Carvalho, 1998, p.46). Representante dessa fidalguia e de seus valores e, ao mesmo tempo, defensor da modernização, Nabuco propugna, em níveis cultural e econômico, valores contraditórios. Mas Nabuco de Araújo foi advogado, além de político, fato que seu biógrafo menciona quase de relance, por não condizer com a imagem idealizada de um político absolutamente alheio a valores materiais que é dele traçada. Como acentua Coelho,

Nabuco dedica umas poucas páginas à atividade advocatícia do pai (mais precisamente 16 páginas

Anos 90, Porto Alegre, v. 11, n. 19/20, p.319-346, jan./dez. 2004 
numa obra em quatro volumes), assim mesmo para defendê-lo de acusações ou insinuações de comportamento pouco ético. Seja como for, talvez sua percepção da advocacia refletisse a opinião do pai que declarara ter exercido a profissão apenas para poder pagar dívidas (Coelho, 1999, p.174).

Eram esses, de fato, os valores da elite pernambucana? Outras perspectivas são menos apologéticas. A aparente benevolência do senhor de engenho nordestino é, para Eisenberg, um conceito sem foros de realidade criado por essa própria elite. Segundo o autor, a defesa do trabalho compulsório feita repetidas vezes pelos senhores de engenho, pouco antes da abolição, exprimiu, antes de tudo, a dificuldade destes em adaptarem-se às relações capitalistas baseadas no trabalho livre. Ademais, como Nabuco e, décadas mais tarde, Gilberto Freyre querem fazer crer, a menor predominância de relações capitalistas verificada nessa região não correspondeu a uma maior suavidade no relacionamento entre senhor e escravo (Eisenberg, 1977, p.187-192.213). A propósito, Freyre sente-se plenamente identificado com Nabuco, definindo o papel histórico por ele desempenhado como "o papel de revolucionário, conservando" (Freyre, 1966, p.89). Vindo de Freyre, não pode haver elogio maior.

Acrescente-se que naquela sociedade, como tende a ocorrer em sociedades escravistas, o status positivo é proporcionado não pela posse de capital, mas pela posse de escravos. Cria-se uma ideologia anticapitalista na qual o trabalho converte-se em elemento desvalorizado. Mantém-se a ética do fidalgo.

Abolição e Proclamação da República são divisores de água na vida e no pensamento de Nabuco. Mantendo-se fiel ao monarquismo, ao mesmo tempo que rompe com o movimento monarquista ou é abandonado por ele ao aderir ao governo republicano, seu pensamento sofre uma nítida inflexão, tornando-se cada vez mais conservador. Nesse momento, Nabuco torna-se um cioso defensor da necessidade de se preservarem as tradições, demolindose apenas o que seja prejudicial e mantendo-se mesmo

Anos 90, Porto Alegre, v. 11, n. 19/20, p.319-346, jan./dez. 2004 
Tradição, identidade nacional e modernidade em Joaquim Nabuco

o que seja inútil. Ele define, a partir daí, seu modelo de transformação social: "Nenhum explosivo é legítimo, porque a ação não pode ser de antemão conhecida; é preciso demolir a nível e compasso, retirando pedra por pedra, como foram colocadas" (Nabuco, s/d, p.140).

A questão a definir aqui é se Nabuco tornou-se conservador com o passar do tempo, ou se ele foi, desde sempre, um nostálgico de tradições passadas, forçado a adotar uma postura radical devido à necessidade de lutar pela abolição. Porém, concluída a luta, voltou a seu conservadorismo inicial, representando seu pensamento e ação nos anos 80, durante o abolicionismo, um hiato em sua carreira, como acentua Nogueira (1984, p.113). Seu reformismo radical casase, um tanto paradoxalmente, com seu conservadorismo inato, de forma que transformações revolucionárias ou um processo de mudanças que contasse com a participação popular e ameaçasse colocar em risco a ordem nacional são sempre rejeitados. Trata-se de uma mistura de conservadorismo e luta por reformas, enfim, definida com precisão por Vianna Filho (1949, p.25):

Numa palavra, a ânsia de reforma, tão viva e ardente em Nabuco, era refreada pela idéia ou pelo sentimento duma evolução natural, progressiva, e que não abrisse oportunidade a subversões de conseqüências mais ou menos.

Da mesma forma, portanto, como o abolicionismo de Nabuco encontra limites por ele mesmo definidos na recusa de envolver escravos no movimento, por temer uma rebelião de conseqüências imprevisíveis, seu monarquismo pauta-se pela intransigente recusa de perturbar a ordem estabelecida. Seus princípios e sentimentos monarquistas permanecem, apenas, princípios e sentimentos. Não evoluem para a prática transformadora, pela recusa de Nabuco em corroborar qualquer transformação política revolucionária.

Anos 90, Porto Alegre, v. 11, n. 19/20, p.319-346, jan./dez. 2004 
O tradicionalismo de Nabuco não remete, por outro lado, ao lusitanismo que foi, por exemplo, o de Varnhagen. Se não chega a antecipar o antilusitanismo ferrenho de um Manoel Bonfim, Nabuco tampouco é simpático à colonização portuguesa, chegando a acentuar, em discurso pronunciado em 1880, as liberdades de consciência e de comércio que os holandeses trouxeram ao Brasil e que teriam prevalecido em caso de sua vitória. Além disso, como acentua Mello, se sua crítica toma como base as conseqüências do escravismo e não da colonização portuguesa, esta carrega a responsabilidade de ter introduzido o escravo no Brasil (Mello, 1997, p.395).

O monarquismo de Nabuco nunca será, de qualquer forma, militante como o é seu abolicionismo. Durante a Revolta da Armada, em 1893, Nabuco escreve uma série de artigos francamente favoráveis aos revoltosos e críticos em relação a Floriano (Hanner, 1975, p.111), contudo não indo além disso, apesar de ele ver, no jacobinismo florianista, um modismo passageiro mas perigoso, por desprezar as instituições liberais (Queiroz, 1986, p.166). Nabuco será, então, mais apologético da monarquia que crítico da república. Tal monarquismo será publicista a princípio, historiográfico depois (quando escreve Um Estadista do Império, a biografia de seu pai e, de certa forma, do próprio Império) e finalmente memorialista (quando escreve Minha Formação).

O tradicionalismo do autor reflete-se, ainda, em sua formação cultural. Se ele foi um reformista em termos sociais, ele foi também um conservador no que tange à cultura. Nabuco repudia o surgimento do mercado cultural e proclama os escritores a darem as costas a esse negócio. Para ele, o mercado de livros matou a obra literária. Desde que as letras tornaram-se fonte de renda, era forçoso transformar-se o literato também em industrial, e a profissão de escritor é, talvez, a que mais deforma o talento; sua obra torna-se assim odiosa como a tarefa do escravo (Nabuco, 1949b, p.111.3).

Gilberto Freyre (1960, v. I, p.53) filia Nabuco ao que chama de "tradição recifense de contato acadêmico e principalmente extraacadêmico de intelectuais, homens públicos, e estudantes mais

Anos 90, Porto Alegre, v. 11, n. 19/20, p.319-346, jan./dez. 2004 
inquietos com idéias européias ou anglo e hispano-americanas de reforma social". Com isso, visa explicar, como deserção, o engajamento de um aristocrata em todo um processo de reformas sociais que colocavam em risco a sobrevivência da própria elite da qual Nabuco era filho. Mas será possível falarmos em deserção, se Nabuco permanece fiel a valores por ele identificados como específicos dessa elite? Não seria mais correto falarmos em um representante dessa elite lúcido o suficiente para perceber que os padrões de dominação social baseados na escravidão tornaram-se irremediavelmente anacrônicos, e que o inevitável processo de modernização a ser seguido implicava a adoção do trabalho livre? A dominação por parte de tais elites, de resto, em momento algum é posta em questão por Nabuco; trata-se, antes, de modernizá-la.

Tais vinculações, contudo, são complexas. Se Nabuco é filho, como Freyre o seria, das elites patriarcais pernambucanas, é importante salientar, por outro lado, que suas bases eleitorais pertenciam ao proletariado recifense. Como acentua Chacon (1981, p.129), "o próprio Nabuco era eleito, quase sempre, pela circunscrição do bairro do São José, habitado por artesãos livres e baixa classe média: um típico proletarismo da época". A integração entre Nabuco e seu eleitorado não foi, contudo, um modelo de harmonia, tendo sido ele quase vaiado nas ruas do Recife, "onde lhe sentiam talvez aroma de aristocrata desgarrado entre a plebe" (Freyre, 1937, p.270), o que ele, de fato, era.

Já as elites pernambucanas dividem-se quanto à maneira de avaliar a trajetória política de Nabuco. Fica como exemplo um relato de Júlio Bello, filho de família tradicional e futuro senhor de engenho. No internato no qual morava quando adolescente, tomase conhecimento de um triunfo de Nabuco. Os filhos das famílias conservadoras vestem-se de luto; os liberais e abolicionistas exultam:

Eu era, naquela época distante, um pirralho de 13 anos, que me dava por snobismo ao luxo de ser republicano. De família tradicionalmente liberal, gozei

Anos 90, Porto Alegre, v. 11, n. 19/20, p.319-346, jan./dez. 2004 
no íntimo a vitória do admirável paladino abolicionista (Bello, 1944, p.69).

Nabuco foi, sim, tradicionalista. Seu apego à tradição fica patente em um episódio no qual um deputado republicano mineiro recusa-se a proferir o juramento católico regimental para tomar posse, e ele propõe: "Ao menos que ele jure defender a religião do Estado. Ele não é monarquista mas é católico. Assim poderá entrar na Câmara" (Dornas Filho, 1936, p.56).

A sociedade brasileira, porém, não criou, segundo ele, uma tradição que a fundamentasse. Aqui, a família carece de unidade, e “a terra não tem valor moral como laço de união social". Não temos tradições, não a preservamos. Diferimos, por exemplo, da Alemanha: "O tempo é noção secundária na vida de um povo que ainda, como a Alemanha, não rompeu com o seu passado" (Nabuco, 1983, p.392). Espírito tradicionalista, Nabuco lamenta a ausência de laços tradicionais a consolidarem a formação social brasileira.

Para compreendermos a questão da tradição no pensamento de Nabuco, como de resto sua própria trajetória pessoal, política e intelectual, é fundamental situarmos as diferentes etapas a partir das quais ele vivencia o sentimento religioso. Villaça (1975, p.67) sintetiza a trajetória religiosa de Nabuco: "A evolução espiritual de Joaquim Nabuco passou por três fases: uma infância católica, uma juventude cética, a conversão ao catolicismo em plena maturidade, quarenta e três anos". O próprio Nabuco data sua conversão, em carta escrita em 1893: "Nestes últimos anos fez-se em mim uma perfeita evolução católica e a estou escrevendo, ainda que não para o público" (Nabuco, 1949d, v. I, p.221). Oliveira Lima, que o conheceu bem, define a religiosidade de Nabuco como antes de forma que de essência (Lima, 1937, p.26). De fato, um certo ceticismo permanece latente quando Nabuco (1949b, p.195) afirma: "A religião pode ser uma grande ilusão, mas é a ilusão da humanidade toda, ao passo que a irreligião, quando seja a verdade, é a verdade de poucos".

Anos 90, Porto Alegre, v. 11, n. 19/20, p.319-346, jan./dez. 2004 
Em 1879, Nabuco é anticlerical e afirma que "a Igreja tem sido a mais constante perseguidora do espírito de liberdade, a dominadora das consciências, até que se tornou inimiga irreconciliável da expansão científica e da liberdade intelectual no nosso século" (Nabuco, 1983, p.123). A Igreja seria, ainda, um entrave - o principal - à modernização. É devido à sua influência, assevera Nabuco, que as civilizações latinas são incapazes de acompanhar as civilizações anglo-saxônicas (ibid., p.130).

Ainda no mesmo ano - durante a Questão Religiosa, portanto - Nabuco ironiza as posições assumidas pela Igreja a partir da condenação de alguns de seus bispos: "Sendo assim, com a prisão, os dignos prelados nada perderam e ganharam a fama de mártires, que no futuro lhes dará direito à canonização" (Nabuco, 1983, p.211). Em discurso pronunciado no ano seguinte, o autor estende sua crítica ao catolicismo, definindo a religião católica como a exploração de uma política tendo como pretexto o sentimento religioso (ibid., p.240). Finalmente, o ceticismo de Nabuco juntase à crítica que faz da Igreja, denunciada como conivente no que tange à questão escrava. Para ele, "nem os bispos, nem os vigários, nem os confessores, estranham o mercado de entes humanos; as Bulas que o condenam são hoje obsoletas" (Nabuco, 1983, p.167). Já em sua autobiografia - balanço de sua trajetória, definição de novos ideais e acerto de contas com seu passado -, Nabuco não apenas enfatiza sua reconversão ao catolicismo, como renega seu passado distante da Igreja:

Do que preciso fazer renúncia, em favor das traças que o consumiram, é de tudo o que nesses opúsculos escrevi em espírito de antagonismo à religião, com a mais soberba incompreensão de seu papel e da necessidade, superior a qualquer outra, de aumentar a sua influência, a sua ação formativa, reparadora, em todo o caso, consoladora, em nossa vida pública e em nossos costumes nacionais, no fundo transmissível da sociedade (Nabuco, s/d, p.36).

Anos 90, Porto Alegre, v. 11, n. 19/20, p.319-346, jan./dez. 2004 
Descrevendo ainda os sentimentos religiosos de Nabuco de Araújo e sua ação política durante a Questão Religiosa, ele afirma:

Nabuco era um verdadeiro católico, um estadista convencido da necessidade de amparar e desenvolver o sentimento religioso, como o meio único de regeneração e aperfeiçoamento da sociedade, a base permanente de todas as suas instituições e relações morais, de justiça, de liberdade e de direito (Nabuco, 1936, vol. II, p.271).

Descrevendo seu pai, de certa forma, é a si próprio que Nabuco descreve; são suas convicções de convertido ao catolicismo que ele exprime. Mesmo se visse o catolicismo como obstáculo à modernidade, nesta declaração de princípios feita de modo enviesado, o empecilho desaparece: "Basta dizer que ele não compreendia sociedade sem moral, moral sem Igreja, e que não via no catolicismo um obstáculo, mas a condição do progresso humano" (Nabuco, 1936, v. II, p.277). Modernidade e religião não podem, enfim, caminhar separadas. Nesse sentido, Nabuco faz o elogio da ação jesuítica no Brasil e ressalta a importância da religião como guardiã das tradições e do caráter moral brasileiro, defendendo-a nestes termos:

Cada dia o papel da religião cristã, na sua forma unitária, que é o catolicismo, parece maior e mais necessário... A ciência não será jamais o culto senão de uma pequena parcela da humanidade. As massas se dividirão entre dois cultos: o de Deus e o do dinheiro (Nabuco, 1949d, v. I, p.41.8).

$\mathrm{Na}$ defesa da religião, Nabuco mostra, assim, seu apego às tradições, sendo sua conversão fundamental para compreendermos a evolução de seu pensamento. Esse trecho deixa claro não apenas a importância essencial da religião na última etapa de sua vida e de sua obra, como a própria importância que o autor atribui, a partir

Anos 90, Porto Alegre, v. 11, n. 19/20, p.319-346, jan./dez. 2004 
Tradição, identidade nacional e modernidade em Joaquim Nabuco

daí, ao papel a ser desempenhado pela Igreja na vida brasileira: papel formativo, consolidador dos costumes, das tradições. Nabuco, mais que nunca, é tradicionalista.

Tradicionalismo, modernidade e abolicionismo são questões entrelaçadas na obra de Nabuco. Tratava-se de libertar o escravo da escravidão e o Brasil do escravo, para que a tradição pudesse ser mantida a salvo da corrupção introduzida pelo cativo, e a modernidade pudesse, enfim, se instalar livre de sua presença.

\section{Abolicionismo e monarquismo}

Escrevendo em 1900, Nabuco faz um balanço das análises até então efetuadas sobre o abolicionismo, apontando dois pontos de vista contrastantes: um que vê no abolicionismo "um movimento popular de tendências revolucionárias, que acabou por forçar o governo e a dinastia", e outro que realça o papel decisivo desempenhado pela própria Coroa, por ter ela assinado as leis de 1871 (em um momento, segundo ele, em que não havia nenhuma agitação nesse sentido) e de 1888 (Nabuco, 1949c, p.247.9). Sua linha interpretativa filia-se, claramente, à segunda tendência, e temos um exemplo disso quando Nabuco define o discurso feito por Pedro II no Conselho de Estado como o fator de criação da questão servil, até então não posta em discussão (Nabuco, 1936, v. II, p.24).

Enquanto dura a luta pela abolição, contudo, Nabuco critica a atitude tíbia adotada pela Monarquia em frente à questão. Tal crítica incide em três pontos que o autor sintetiza em carta a Patrocínio: nunca cumpriu a lei de 1831, que proibia o tráfico negreiro; deixou revogar a Lei do Ventre Livre; e chamou ao poder os conservadores em meio à luta emancipacionista (Nabuco, 1949d, v. I, p.149). O Nabuco abolicionista atribui, à monarquia, a maior parte do que até então foi feito em termos de esforços abolicionistas, para em seguida acrescentar: "mas o que não se tem feito, podendose fazer mas com vantagem, deve ser levado à mesma conta" (Nabuco, 1949a, p.100). Na contabilidade do feito e do por fazer, o resultado final, conclui Nabuco, é amplamente desfavorável ao Imperador:

Anos 90, Porto Alegre, v. 11, n. 19/20, p.319-346, jan./dez. 2004 
O que se tem feito por lei é devido principalmente a ele, mas o que a lei tem feito é muito pouco, é realmente nada, quando vemos que esse é o resultado de quarenta e seis anos de reinado e comparamos o que se salvou do naufrágio com o que se perdeu e se está perdendo! (Nabuco, 1949a, p.244).

Pedro II é diretamente responsabilizado pela reação conservadora que se estruturou nos anos 80 , a qual teria tido, nele, seu idealizador (Nabuco, 1949a, p.257). A crítica de Nabuco faz eco, enfim, à então imagem corrente de Pedro II: a de um monarca mais preocupado com os estudos, aos quais se entrega com o ardor e a imperícia de um diletante - a astronomia, por exemplo -, que com os mais urgentes problemas nacionais. Nabuco desfere uma dura crítica ao Imperador, lembrando que "o que ele fez é nada ao lado do que ele podia ter feito, se a observação das senzalas lhe causasse tanto interesse como, por exemplo, a contemplação do céu" (Nabuco, 1949a, p.252). Esse é um Nabuco, portanto, muito diferente do nostálgico e reverente monarquista que surgirá após a Proclamação.

Crítico de Pedro II durante todo o processo abolicionista, Nabuco vê a monarquia com outros olhos após seu fim, quando ele se decide a escrever a história do regime tomando, como ângulo, a vida de seu pai. A monarquia foi democrática, afirma ele: "entre a democracia e a monarquia, no Brasil, houve por vezes desinteligências e rupturas, mas nunca verdadeiro antagonismo" (Nabuco, 1936, v. I, p.60). Mesmo a responsabilidade pessoal do Imperador parece esvanecer-se, diluída em uma culpa compartilhada por todos os homens públicos. Segundo Nabuco (1936, v. I, p.186),

[...] todos os homens de governo entre nós, todos os depositários de uma parcela que fosse de autoridade, durante o período da escravidão, concorreram, direta ou indiretamente, para sustentar uma tirania pérfida, inquisitorial, torturante.

Anos 90, Porto Alegre, v. 11, n. 19/20, p.319-346, jan./dez. 2004 
Tradição, identidade nacional e modernidade em Joaquim Nabuco

A maneira como Nabuco vê e analisa a atuação do Poder Moderador muda radicalmente. Em 1883, ele assim o define:

Autônomo, só há um poder, entre nós, o poder irresponsável; só esse tem certeza do dia seguinte; só esse representa a permanência da tradição nacional. Os ministros não são mais que as encarnações secundárias, e às vezes grotescas, dessa entidade superior (Nabuco, 1983, p.171).

Vinte anos depois, a conclusão é oposta:

A verdade é que o Imperador nunca quis fazer de seus ministros instrumentos; para isto seria preciso que ele quisesse governar por si, o que ele não podia fazer... Não os queria soberbos, não os conservaria servis (Nabuco, 1936, v. I, p.249)

Nabuco atribui a Pedro II, em síntese, o papel histórico de superintendente a traçar as linhas gerais - utilizando, inclusive, tal expressão -, deixando a administração por conta dos ministros. Não se trata, aqui, de entrar no mérito de qual foi o papel desempenhado pelo Imperador, mas de constatar a mudança evidente no perfil traçado por Nabuco, passando da crítica à admiração. Os defeitos estruturais do sistema político imperial não derivam da vontade e das atitudes de Pedro II, sendo ele, pelo contrário, "o mais estrênuo e sincero apologista que a liberdade e a pureza das eleições teve em seu reinado". Foram os partidos que deturparam tudo:

Eram os vícios, a intolerância, a cobiça dos próprios partidos, nenhum dos quais deixava ao adversário na legislatura um só lugar que lhe pudessem tomar pela fraude, pela violência, pela corrupção, o que tornava a eleição um simulacro, e portanto definitiva, e não simplesmente interlocutória, a sentença da dissolução (Nabuco, 1936, v. II, p.93).

Anos 90, Porto Alegre, v. 11, n. 19/20, p.319-346, jan./dez. 2004 
Ele próprio um liberal, Nabuco ressalta a inconsistência doutrinária dos partidos imperiais, sempre prontos a seguirem políticas pouco ou nada condizentes com seus princípios partidários:

Não era a qualificação de conservador que impediria um desses partidos de oferecer-se para as inovações as mais ousadas, como não era o de liberal que tolheria o outro de secundar as medidas as mais autoritárias (Nabuco, 1936, v. II, p.117).

Um dos fatores que inviabilizariam a adoção do regime democrático, no Brasil, seria o personalismo imperante na atividade política, o que Nabuco constata em 1886, ao afirmar: "a adesão dos partidários no Brasil não é a idéias, mas a homens" (Nabuco, 1949a, p.189). A monarquia brasileira representaria, então, o ápice do personalismo político, uma vez que "todo o nosso sistema de governo assenta sobre a vontade de um só homem, cuja inteligência é o limite da nossa vida nacional" (Nabuco, 1949a, p.223). Caberia ao liberalismo criar mecanismos de atuação que se situassem além da vontade e dos limites impostos pelo Poder Moderador. Só assim liberalismo e abolicionismo poderiam se fundir, e só assim o liberalismo brasileiro teria justificada sua existência.

Nabuco sempre lutou pela democratização da vida política brasileira, servindo de exemplo as críticas feitas por ele à Lei Saraiva, promulgada em 1881, que restringia drasticamente o direito de voto a partir de critérios ligados à riqueza e profissão, fazendo desaparecer contingentes inteiros de eleitores. Nesse momento, lembra Rodrigues (1982, p.157), Nabuco afirma não conhecer "nenhum título no homem de dinheiro que o torne melhor do que qualquer outro cidadão brasileiro para se fazer representar no Parlamento", sendo seu objetivo a democratização da vida partidária. Referindo-se ao autor, Prado (1999, p.261) salienta: "A reforma partidária que advogava objetivava a constituição de um partido popular, comprometido com o povo e com as reformas sociais".

A monarquia constitucional, tal como existente na Inglaterra é, para Nabuco, o mais democrático dos regimes, por manter o 
Tradição, identidade nacional e modernidade em Joaquim Nabuco

governo sempre nas mãos da representação nacional, enquanto que, em uma república como a americana, o povo limita-se a escolher seus representantes. Conclui ele: "Comparando os dois governos, o norte-americano ficou-me parecendo um relógio que marca as horas da opinião, o inglês, um relógio que marca até os segundos" (Nabuco, 1949c, p.28). A descrição que Nabuco faz do gabinete liderado por Paraná, em 1850, é fundamental para compreendermos seu pensamento político:

A autoridade sente-se moralmente responsável; o ministro não é um déspota que possa levar de rojo câmaras e partido, acima deles está a Coroa, está opinião de seus pares, estão os princípios geralmente aceitos, está o espírito de moderação e a rotina dos precedentes (Nabuco, 1936, v. I, p.257).

O liberalismo de Nabuco é, finalmente, definido de forma comparativa e com precisão por Oliveira Vianna, que vê, em Joaquim Nabuco e em Rui Barbosa, representantes exemplares do liberalismo brasileiro às vésperas da proclamação da República:

Rui e Nabuco, um e outro exprimiam perfeitamente o estado do pensamento liberal do país, no período imediatamente precursor da queda do velho regime e que era: ou de simpatia, ou de indiferença pela Monarquia; mas, não, nunca, de crença no regime contrário - no regime republicano (Vianna, 1990, p.94).

O monarquismo de Nabuco - e, concomitantemente, seu antirepublicanismo - é, ainda, de fundo moral. Diferente da República, a Monarquia deriva sua legitimidade - e sua superioridade - da tradição e da moral: "O respeito à dignidade da nação, o desejo de vê-la altamente reputada no mundo, era natural na monarquia, que era o governo pela força moral somente" (Nabuco, 1937, p.180).

Anos 90, Porto Alegre, v. 11, n. 19/20, p.319-346, jan./dez. 2004 
A opinião pública é o fundamento da atividade política, e foi exatamente a construção desse fundamento que a escravidão inviabilizou. Segundo Nabuco, "não há, com a escravidão, essa força poderosa chamada opinião pública, ao mesmo tempo alavanca e o ponto de apoio das individualidades que representam o que há de mais adiantado no país" (Nabuco, 1977, p.170). Com isso, a vida política é mutilada, e o Poder Moderador reina absoluto e sem contrastes.

Conforme Nabuco, "antes de tudo, o Reinado é do Imperador... opor-se a ele, aos seus planos, à sua política, era renunciar ao poder" (Nabuco, 1936, v. II, p.374). O personalismo que a proeminência do Poder Moderador impõe ao sistema parlamentar debilita-o e constituiu-se na negação do sistema político preconizado por Nabuco, já que este tem seu eixo no equilíbrio e rotatividade do poder. Mas as origens de tal situação não se encontram nele mesmo: é a própria sociedade brasileira, são as características de sua população que, na perspectiva de Nabuco, desfiguram o ideal político e tornam inviável sua adoção. Referindo-se, então, ao Poder Moderador, Nabuco conclui:

Se é um poder sem contraste, não é por culpa dele, mas pela impossibilidade de implantar em uma população como a brasileira a verdade eleitoral, e porque a verdade eleitoral ainda tornaria o eleitorado mais adeso ao governo qualquer que fosse, isto é, ao poder que tinha o direito de nomear (Nabuco, 1936, v. II, p.377).

Desaparecida a Monarquia, Nabuco mantém-se leal a ela não por uma questão de fidelidade pessoal, mas por motivos muito próximos aos que o fizeram recusar o republicanismo quando jovem: a defesa de ideais e de uma certa estética ligada à monarquia, os quais ele busca definir: 
Tradição, identidade nacional e modernidade em Joaquim Nabuco

A muitos é impossível deixar de ver no ocupante do trono o homem ou a mulher, o acidente ou a pessoa, para ver a função, a existência tradicional, a lei do movimento político. Desses pode-se dizer que são deficientes em imaginação simbólica; mas, desaparecendo o simbolismo, podemos estar certos de que desaparecerá também o ideal na religião, na poesia, na arte, na sociedade, no Estado (Nabuco, 1949c, p.131.2).

O monarquismo de Nabuco é de origem tanto estética quanto política, o que ele deixa claro ao ressaltar seu desinteresse político quando chega de sua primeira viagem à Europa. Essa indiferença englobava tudo que lembrasse republicanismo, e que é por ele justificado "porque a minha estética política tinha começado a tornarse exclusivamente monárquica" (Nabuco, 1949c, p.93). Sua recusa ao republicanismo deriva, assim, de uma postura estética e existencial: "O que me impediu de ser republicano na mocidade, foi muito provavelmente o ter sido sensível à impressão aristocrática da vida" (Nabuco, 1949c, p.124).

A república latino-americana, para Nabuco, é uma espécie de monarquia degenerada, o que o leva a esta comparação: "Muito mais extensa e profunda do que a degeneração republicana da monarquia no Brasil é a degeneração monárquica da república em toda a América do Sul" (Nabuco, 1990, p.40). Mas como, enfim, Nabuco aderiu à República? A adesão de Nabuco ao regime republicano teria se dado por intermédio de Rio Branco, responsável por sua nomeação como Ministro Plenipotenciário em Londres e representante brasileiro na questão das Guianas. Monarquista como Nabuco, Rio Branco havia feito a transição com relativa facilidade, ao passo que "Joaquim Nabuco fora tão longe na sua intransigência que, podia-se dizer, havia cortado as pontes atrás de si" (Rio-Branco, 1942, p.137).

A decisão de aceitar um cargo no governo Campos Salles gerou críticas ferozes a Nabuco por parte dos monarquistas, que acentuavam não apenas sua traição, mas também seu pouco ou nenhum

Anos 90, Porto Alegre, v. 11, n. 19/20, p.319-346, jan./dez. 2004 
envolvimento efetivo com o movimento. Como acentua Janotti (1986, p.172):

[...] o "caso Nabuco" tornou-se alvo de artigos de jornais republicanos e monarquistas durante o mês de abril de 1899. Estava na ordem do dia a discussão de um princípio caro aos restauradores: a não aceitação de cargos públicos no regime republicano.

\section{Situando Nabuco}

Sem ambições teóricas, sem a preocupação obsessiva de casar as teorias de seu tempo com a realidade brasileira (um casamento raramente bem-sucedido), Nabuco viu-se livre para encarar tal realidade sem os binóculos teóricos que impediram tantos de seus contemporâneos de enxergá-la de forma mais precisa. Nabuco explicou o Brasil por meio da organização econômica do País e a partir das relações de trabalho nele existentes, ignorando as explicações ligadas ao meio e à raça às quais Euclides e Romero, entre outros, apegaram-se. Nesse sentido, o "elitista, aristocrático e europeizado" Nabuco foi, provavelmente, o mais radical e inovador pensador entre seus contemporâneos.

Ao centrar o foco na organização econômica e social brasileira, Nabuco criou o contraponto a toda a discussão sobre a identidade nacional delineada por seus contemporâneos. Ele não a problematizou nem a cultuou exatamente porque, como acentua Mello, ignorou qualquer pretensão brasileira à originalidade. Somos uma nação marcada pela herança do escravismo e, nesse sentido, compartilhamos da mesma característica nacional de tantos países americanos (inclusive os Estados Unidos) marcados pela mesma herança (Mello, 2002, p.238). É a escravidão que nos define, não qualquer identidade mais ou menos nacional, mais ou menos específica. Dessa constatação, deriva a originalidade de Nabuco, do fato de ele ter situado em termos socioeconômicos precisos o debate sobre identidade nacional, tradição e modernidade. 
Tradição, identidade nacional e modernidade em Joaquim Nabuco

\section{Tradition, national identity and modernity in: Joaquim Nabuco}

Abstract. The works of Joaquim Nabuco articulate social and political analysis taking, In: first place, the abolitionism as a center issue. In a second stage, taking as watershed the abolition and republic, the historian and memorialist worried about the rescue and preservation of traditions of monarchy period become more relevant. The purpose of the text is to analyze the evolution of the author's thoughts, taking both phases as parameters, as well as the debate on national identity, tradition and modernity.

Keywords: Monarchy. Tradition. Modernity. Politics.

\section{Referências}

ATHAYDE, Tristão de. Politica e letras. In: CARDOSO, Vicente Licínio (Org.). À margem da história da República. Recife: Fundação Joaquim Nabuco; Editora Massangana, 1990.

BELLO, Júlio Maria. Memórias de um senhor de engenho. Rio de Janeiro: José Olympio, 1944.

BELO, José Maria. Inteligência do Brasil. São Paulo: Nacional, 1935.

CARVALHO, Maria Alice Resende de. O quinto século: André Rebouças e a construção do Brasil. Rio de Janeiro: Revan; Editora da IUPERJ, 1998.

CHACON, Wamireh. História das idéias socialistas no Brasil. Rio de Janeiro; Fortaleza: Civilização Brasileira; Edições UFC, 1981.

COELHO, Edmundo Campos. As profissões imperiais: medicina, advocacia e engenharia no Rio de Janeiro, 1822-1930. Rio de Janeiro: Record, 1999.

DORNAS FILHO, João. Silva Jardim. São Paulo: Nacional, 1936.

EISENBERG, Peter. Modernização sem mudança. Rio de Janeiro; Campinas: Paz e Terra; Editora da UNICAMP, 1977.

FERNANDES, Florestan. A revolução burguesa no Brasil. Rio de Janeiro: Zahar, 1975.

FRÉCHES, Claude-Henri. Joaquim Nabuco. Revista do Instituto de Estudos Brasileiros, São Paulo, n. 6., 1969.

FREYRE, Gilberto. Nordeste. Rio de Janeiro: José Olympio, 1937. Ordem e progresso. Rio de Janeiro: José Olympio, 1959.

Anos 90, Porto Alegre, v. 11, n. 19/20, p.319-346, jan./dez. 2004 


\section{Ricardo Luiz de Souza}

FREYRE, Gilberto. Um engenheiro francês no Brasil. Rio de Janeiro: José Olympio, 1960.

Quase política. Rio de Janeiro: José Olympio, 1966.

HANNER, June E. Relações entre civis e militares no Brasil (1889- 1930). São Paulo: Alfa-Ômega, 1975.

JANOTTI, Maria de Lourdes Mônaco. Os subversivos da República. São Paulo: Brasiliense, 1986.

LECLERC, Max. Cartas do Brasil. São Paulo: Nacional, 1942.

LIMA, Oliveira. Memórias. Rio de Janeiro: José Olympio, 1937.

LUXEMBURGO, Rosa. A questão nacional e a autonomia. Belo Horizonte: Oficina de Livros, 1988.

MELLO, Evaldo Cabral de. Rubro veio: o imaginário da restauração pernambucana. Rio de Janeiro: Top Books, 1997.

34, 2002.

Um imenso Portugal: história e historiografia. Rio de Janeiro: Editora

NABUCO, Carolina. A vida de Joaquim Nabuco. Rio de Janeiro, América=EDIT, 1952

NABUCO, Joaquim. Minha formação. Rio de Janeiro: W. M. Jackson, s.d. Um estadista do Império. Rio de Janeiro; São Paulo: Nacional;

Civilização Brasileira, 1936. Balmaceda. São Paulo: Nacional, 1937.

- Campanhas de imprensa. São Paulo: Ipê, 1949a.

Escritos e discursos literários. São Paulo: Ipê, 1949b.

Pensamentos soltos. São Paulo: Ipê, 1949c.

- Cartas a amigos. São Paulo: Ipê, 1949d.

. O abolicionismo. Petrópolis: Vozes, 1977.

. Perfis parlamentares. Brasília: Câmara dos Deputados, 1983.

1988

A escravidão. Recife: Fundação Joaquim Nabuco; Editora Massangana,

O dever dos monarquistas. In: SILVA, Leonardo Dantas (Org.).

Nabuco e a República. Recife: FUNDAJ; Massangana, 1990.

Anos 90, Porto Alegre, v. 11, n. 19/20, p.319-346, jan./dez. 2004 
Tradição, identidade nacional e modernidade em Joaquim Nabuco

NOGUEIRA, Marco Aurélio. As desventuras do liberalismo: Joaquim Nabuco, a monarquia e a república. Rio de Janeiro: Paz e Terra, 1984.

POPPER, Sir Karl R. A sociedade aberta e seus inimigos. Belo Horizonte: Itatiaia; EDUSP, 1974.

PRADO, Maria Emília. O cavaleiro andante dos princípios e das reformas: Joaquim Nabuco e a política In: (Org.). O Estado como vocação: idéias e práticas políticas no Brasil oitocentista. Rio de Janeiro: Access, 1999.

QUEIROZ, Suely Robles Reis de. Os radicais da República. São Paulo: Brasiliense, 1986.

REBOUÇAS, André. Diário e notas autobiográficas. Rio de Janeiro: José Olympio, 1938.

RIO-BRANCO, Raul do. Reminiscências do Barão do Rio Branco. Rio de Janeiro: José Olympio, 1942.

RODRIGUES, José Honório. Conciliação e reforma no Brasil: um desafio histórico-cultural. Rio de Janeiro: Nova Fronteira, 1982.

SCHWHARZ, Roberto. Duas meninas. São Paulo: Companhia das Letras, 1997.

TOCQUEVILLE, Alexis de. A democracia na América. Belo Horizonte; São Paulo: Itatiaia; EDUSP, 1977.

VIANNA, Oliveira. Introdução à história social da economia pré-capitalista no Brasil. Rio de Janeiro: José Olympio, 1958.

O ocaso do Império. Recife: FUNDAJ; Massangana, 1990.

VIANNA Filho, Luis. Rui e Nabuco. Rio de Janeiro: José Olympio, 1949.

VILLAÇA, Antônio Carlos. O pensamento católico no Brasil. Rio de Janeiro: Zahar, 1975.

Anos 90, Porto Alegre, v. 11, n. 19/20, p.319-346, jan./dez. 2004 